\title{
GARDENING AND HORTICULTURE
}

450 THE GARDENS BULLETIN. Botanic Gardens, Singapore. 'Published as materials become available.' $\mathrm{S} \$ 6$ per part.

Scientific papers on all botanical subjects.

451 INDIAN HORTICULTURE. Indian Council of Agricultural Research, New Delhi. 4. Annual Rs 5.

Articles on fruit, vegetables and flowers, and how to grow them.

452 INDIAN JOURNAL OF HORTICULTURE. Horticultural Society of India, Institute of Horticultural Research, 255, Upper Palace Orchard, Bangalore 6. 4. Annual \$3.

Official publication of the Horticultural Society of India. Original articles.

453 NATIONAL AGRICULTURAL SOCIETY OF CEYLON-JOURNAL - see Agriculture

454 SOUTH INDIAN HORTICULTURE. South Indian Horticultural Association, Lawley Road, Coimbatore - 3, India. 4. Annual Rs 12. Authors' summaries, original articles, short communications. 